\title{
Biofiltration of mixtures of gas-phase styrene and acetone with the fungus Sporothrix variecibatus
}

Eldon R. Rene, Radka Špačková, María C. Veiga, Christian Kennes

Journal of Hazardous Materials, Volume 184, Issues 1-3, 15 December 2010, Pages 204-214

DOI: 10.1016/j.jhazmat.2010.08.024

\begin{abstract}
The biodegradation performance of a biofilter, inoculated with the fungus Sporothrix variecibatus, to treat gas-phase styrene and acetone mixtures under steady-state and transient conditions was evaluated. Experiments were carried out by varying the gasflow rates $\left(0.05-0.4 \mathrm{~m}^{3} \mathrm{~h}^{-1}\right)$, leading to empty bed residence times as low as $17.1 \mathrm{~s}$, and by changing the concentrations of gas-phase styrene $\left(0.01-6.3 \mathrm{~g} \mathrm{~m}^{-3}\right)$ and acetone $\left(0.01-8.9 \mathrm{~g} \mathrm{~m}^{-3}\right)$. The total elimination capacities were as high as $360 \mathrm{~g} \mathrm{~m}^{-3} \mathrm{~h}^{-1}$, with nearly $97.5 \%$ removal of styrene and $75.6 \%$ for acetone. The biodegradation of acetone was inhibited by the presence of styrene, while styrene removal was affected only slightly by the presence of acetone. During transient-state experiments, increasing the overall pollutant load by almost 3-fold, i.e., from 220 to $600 \mathrm{~g} \mathrm{~m}^{-3} \mathrm{~h}^{-1}$, resulted in a sudden drop of removal efficiency ( $>90-70 \%$ ), but still high elimination capacities were maintained. Periodic microscopic observations revealed that the originally inoculated Sporothrix sp. remained present in the reactor and actively dominant in the biofilm.
\end{abstract}

\section{Keywords}

Biofiltration; Fibre-board industries; Sporothrix variecibatus; Styrene-acetone mixture; Maximum elimination capacity; Transient response 


\section{Introduction}

The rapid development and proliferation of process industries has made problems associated with air pollution a major concern in industrial areas. The Clean Air Act Amendments (CAAA) of 1990 proposed by the United States Environmental Protection Agency (US-EPA) distinguishes 188 air pollutants based on their inherent toxicity. Styrene $\left(\mathrm{C}_{6} \mathrm{H}_{5} \mathrm{CH}=\mathrm{CH}_{2}\right)$ is an important VOC, which is commonly used as a raw material for the synthesis of plastics, synthetic resins, butadiene-styrene latex, styrene co-polymers and unsaturated polyester resins [1]. On the other hand, acetone $\left(\mathrm{CH}_{3}-\mathrm{CO}-\right.$ $\mathrm{CH}_{3}$ ) is a manufactured chemical, that is also found naturally in the environment. Styrene and acetone form a major part of the emissions from fibre-reinforced plastics (FRP) industry [2]. Airborne emissions containing both styrene, a hydrophobic VOC, and acetone, a hydrophilic organic compound, have shown significant effects on human health and the environment. This has led to increased attention from the regulatory authorities that have helped industries to undertake continuous modifications/development in the existing control technologies.

Some of the efforts undertaken to control these emissions have often failed due to the inefficiency of conventional treatment systems such as adsorption, absorption, wet scrubbing, ozonation, catalytic oxidation and incineration. Under such situations, biodegradation of these compounds has always yielded promising results, while biofiltration, under continuous mode, extends the application of microbes for waste-gas treatment. Styrene and acetone removal in biofilters and biotrickling filters has been investigated as individual gas-phase pollutants by a few researchers, where pure strains and/or mixed species of bacteria have generally been tested [3] and [4]. Research pertaining to the application of fungal biofilters to treat VOCs was initiated only recently. A styrene degrading fungus, Sporothrix variecibatus was isolated from a biofilter treating gas-phase styrene. That fungus remained dominant in the biofilter reaching high elimination capacities [5]. In another previous work, this dominant fungus, when inoculated in a biofilter as a pure strain, showed a maximum elimination capacity of $336 \mathrm{~g}$ styrene $\mathrm{m}^{-3} \mathrm{~h}^{-1}$ at an EBRT of $91.2 \mathrm{~s}$ [6]. One of the main advantages of stimulating fungal rather than bacterial growth for the biofiltration of hydrophobic VOCs like styrene is their ability to completely mineralize these compounds under extreme environmental conditions such as acidic $\mathrm{pH}$, low water content and limited nutrient concentration [7]. In fungi, exogenously produced spores are often formed on specialized hyphae and are usually referred to as conidiophores. There are two primary ways in which a conidiophore develops in fungi, i.e., blastic and thallic development. These conidiophores inherently possess the ability to withstand hydrophobic compounds, besides enhancing the absorption and transport of hydrophobic compounds from the contaminated phase to the cell surface [8].

In most of the earlier reported studies on the co-treatment of binary mixtures of gasphase pollutants, either synergistic or antagonistic type interactions have been reported, i.e., the presence of one compound has led to an increase or decrease in the removal of the other compound and vice-versa. Chang and $\mathrm{Lu}$ [9] studied toluene and acetone removal in a trickling biofilter and showed that low acetone loads and medium toluene loads ensured greater than 90\% removal for both compounds, and a maximum elimination capacity (EC) of $160 \mathrm{~g}$ toluene $\mathrm{m}^{-3} \mathrm{~h}^{-1}$ and $20 \mathrm{~g}$ acetone $\mathrm{m}^{-3} \mathrm{~h}^{-1}$ was reported. In another study [10], it was observed that toluene removal was inhibited by the presence of high ethyl acetate concentrations in a wood-chip + compost biofilter, 
and one possible explanation for the inhibition mechanism was attributed to the failure of the toluene degraders to compete for $\mathrm{O}_{2}$ that limited total VOC removal at high concentrations. The maximum EC reported in that study was $300 \mathrm{~g}$ ethyl acetate $\mathrm{m}^{-3} \mathrm{~h}^{-1}$ and $200 \mathrm{~g}$ toluene $\mathrm{m}^{-3} \mathrm{~h}^{-1}$. Liu et al. [11] evaluated two parallel bench-scale biofilters packed with compost, soil and lava rock using indigenous microorganisms and reported that the biodegradation of toluene was suppressed by the presence of ethyl acetate, while the removal of ethyl acetate was not affected by the presence of toluene. At an empty bed residence time (EBRT) of $30 \mathrm{~s}$, the maximum EC were $450 \mathrm{~g}$ ethyl acetate $\mathrm{m}^{-3} \mathrm{~h}^{-1}$ and $50 \mathrm{~g}$ toluene $\mathrm{m}^{-3} \mathrm{~h}^{-1}$. Dehghanzadeh et al. [12] treated styrene and acrylonitrile mixtures in a biofilter packed with yard compost and shredded high density plastics, inoculated with activated sludge microbes. It was envisaged that, acrylonitrile biodegradation was not affected by the presence of styrene in gas-phase, while styrene removal was enhanced in the lower section of the filter bed when acrylonitrile was completely depleted, suggesting the existence of competition for bio-catalytic activity among different microbial populations within the biofilter. The maximum ECs were $103 \mathrm{~g}$ acrylonitrile $\mathrm{m}^{-3} \mathrm{~h}^{-1}$ and $45 \mathrm{~g}$ styrene $\mathrm{m}^{-3} \mathrm{~h}^{-1}$, respectively.

In all the above-mentioned studies, either pure bacterial strains or mixed cultures have been used and very little work has been initiated to study fungal biofilters for treating mixtures of pollutants in gas-phase. The present work was carried out, in an effort to understand the removal characteristics of mixtures of gas-phase pollutants in a biofilter, using S. variecibatus. Styrene was chosen as the hydrophobic VOC, whose removal characteristics using this fungus were well-established earlier as an individual pollutant [6], while acetone was chosen as the hydrophilic organic compound, owing to its tendency to readily biodegrade under aerobic conditions and its presence, together with styrene, in industrial effluents from fiber-board industries.

Biofilters handling industrial waste-gases often receive sudden fluctuations in pollutant loading rates due to changes in process conditions. An active biofilter should be able to handle such adverse situations in order to provide maximum removal of the target contaminant [13] and [14]. However, little information is known about the shock surviving capacity of fungal biofilters, especially when the gas-phase contains more than one pollutant. Also, in industrial situations, there could be complex interactions among different pollutants, and the microorganisms with respect to biodegradability when biofilters experience a sudden, yet unexpected shock load. To understand this phenomenon better, the transient behaviour of the fungal biofilter was investigated by subjecting the fungal biofilter to short-term fluctuations in inlet loads of both styrene and acetone. A new, batch experiments were conducted to understand the kinetics of the removal process, as well as to ascertain some of the experimental observations from the biofilter.

\section{Materials and methods}

\subsection{Nutrient medium and fungal inoculum}

The mineral salt medium used for batch and continuous biofilter experiments had the following chemical composition (per liter in distilled water): $0.5 \mathrm{~g} \mathrm{~K}_{2} \mathrm{HPO}_{4}, 0.1 \mathrm{~g}$ $\mathrm{MgSO}_{4} \cdot 7 \mathrm{H}_{2} \mathrm{O}$, $4.5 \mathrm{~g} \mathrm{KH}_{2} \mathrm{PO}_{4}, 2 \mathrm{~g} \mathrm{NH} 4 \mathrm{Cl}$, and $2 \mathrm{ml}$ vitamins and trace minerals [15]. The original $\mathrm{pH}$ of that medium was adjusted to 5.9. 
The fungus, S. variecibatus, isolated from a previously operated biofilter treating styrene vapours [5], was grown and maintained in a sterile atmosphere on $15 \mathrm{~g} \mathrm{agar}^{-1}$, under ambient conditions. Typical spores of Sporothrix sp., attached to perlite are shown in Fig. 1. The culture medium was autoclaved at $120^{\circ} \mathrm{C}$ for 20 min before adding the filter-sterilized solutions of vitamins and trace minerals. $1 \mathrm{~g}$ oxytetracycline hydrochloride was aseptically added to $1 \mathrm{l}$ of sterilized agar medium to prevent the growth of bacterial colonies. The petri dishes containing the agar medium and styrene utilizing fungus were incubated in a dessicator in presence of styrene vapours, supplied as the sole carbon source for fungal growth.

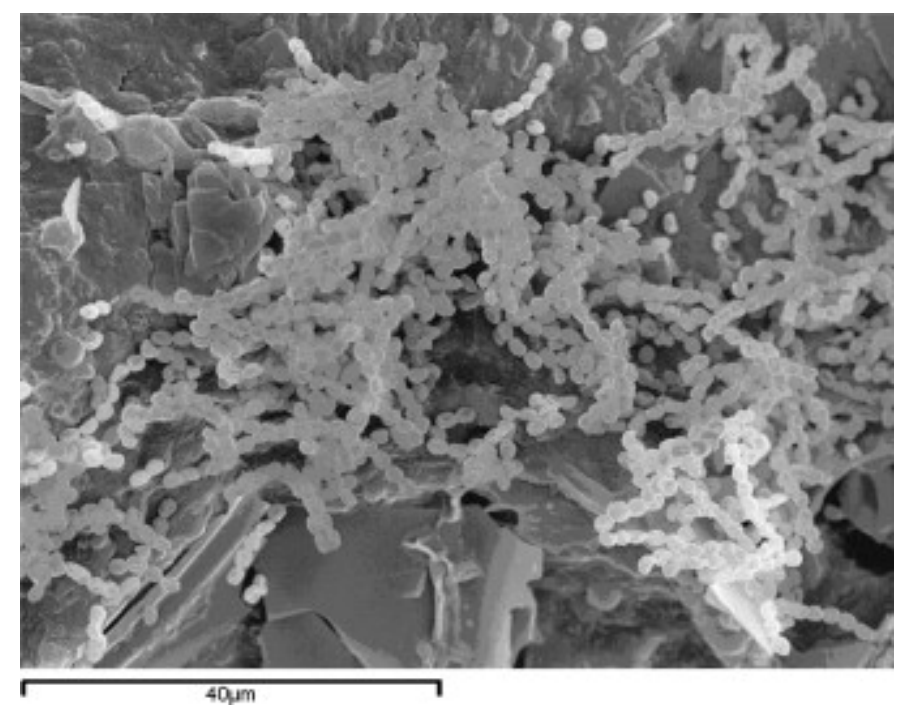

Fig. 1.

SEM photograph of Sporothrix variecibatus.

\subsection{Biofilter setup}

The schematic of the experimental setup is illustrated in Fig. 2. The biofilter was made of glass having an internal diameter of $8 \mathrm{~cm}$ and $70 \mathrm{~cm}$ in height. The packing in the biofilter consisted of sieved perlite beads $(4-6 \mathrm{~mm})$, packed to give a total filter bed volume of $0.0019 \mathrm{~m}^{3}$. A perforated plate at the bottom provided the support for the packing material while another plate at the top acted as a distributor for the gas flow and mineral salt medium addition. Gas sampling ports sealed with rubber septa were provided at equal intervals along the biofilter height. 

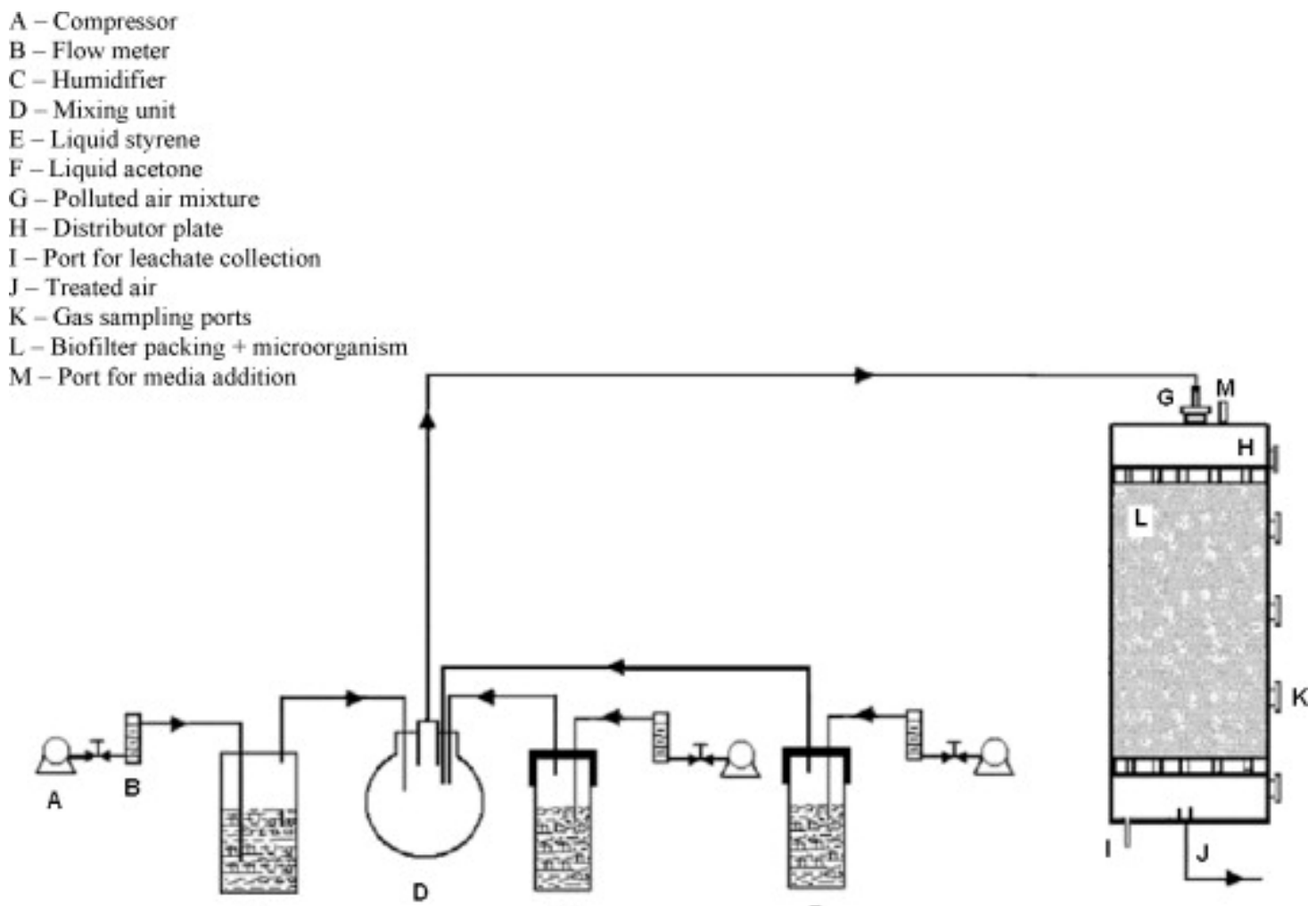

Fig. 2.

Schematic of the experimental setup for styrene and acetone co-treatment.

\subsection{Biofilter inoculation}

S. variecibatus was grown under batch conditions in $1000 \mathrm{ml}$ Erlenmeyer flasks, using equal headspace concentrations of both styrene and acetone $\left(4 \mathrm{~g} \mathrm{~m}^{-3}\right)$ in the media under shaking conditions $(175 \mathrm{rpm})$ and at $30^{\circ} \mathrm{C}$. After $48-56 \mathrm{~h}$ of growth, having reached an optical density (OD) of 1.3 at $600 \mathrm{~nm}$, the cells were harvested by centrifugation at $5000 \mathrm{rpm}$ for $20 \mathrm{~min}$ and re-suspended in $2 \mathrm{l}$ fresh nutrient medium to be used as inoculum for the continuous biofilter. This culture was aseptically added to the biofilter from the top, the leachate then drained after $4 \mathrm{~h}$ and re-supplied several times till visible biomass was noticed on the perlite surface.

\subsection{Biofilter operation}

Humidified styrene and acetone vapors at constant flow rate and concentration, controlled through valves were passed through the bed in a downflow mode. The bed's moisture content was maintained constant by periodic addition of fresh mineral salt medium from the top (once every $3 \mathrm{~d}$ ). Experiments were carried out by varying the flow rates of the styrene and acetone vapors and humidified air ( $>90 \%$ relative humidity) independently to get different initial concentrations and residence times in the biofilter, i.e., 17.1, 34.2, 68.5 and 137 s. Gas samples were collected from different ports located at bed heights of 8.5, 23.5, 38.5 and $49 \mathrm{~cm}$ from the inlet and were later analyzed for residual styrene and acetone concentrations. 
The removal efficiency of the pollutants (RE, \%) and the elimination capacity of the filter bed (EC, $\mathrm{g} \mathrm{m}^{-3} \mathrm{~h}^{-1}$ ), as well as other key parameters, were estimated by the following equations:

Inlet loading rate, $\mathrm{ILR}=\frac{\mathrm{QC}_{\mathrm{i}}}{\mathrm{V}}$

Elimation capacity, $\mathrm{EC}=\frac{Q\left(C_{\mathrm{i}}-C_{\mathrm{o}}\right)}{\mathrm{V}}$

Removal efficiency, RE $=\frac{C_{i}-C_{0}}{C_{i}} \times 100$

Total inlet loading rate, $\mathrm{LLR}_{\text {Total }}=\frac{\mathrm{Q}\left[\mathrm{C}_{\text {styrene, in }}+\mathrm{C}_{\text {acetone, in }}\right]}{\mathrm{V}}$

Total elimination capacity, $\mathrm{EC}_{\text {Total }}$

$$
=\frac{\mathrm{Q}\left[\left(\mathrm{C}_{\text {styrene, in }}+\mathrm{C}_{\text {acetone, in }}\right)-\left(\mathrm{C}_{\text {styrene, out }}+\mathrm{C}_{\text {acetone, out }}\right)\right]}{\mathrm{V}}
$$

where $Q$ is the gas flow rate $\left(\mathrm{m}^{3} \mathrm{~h}^{-1}\right), V$ is the volume of the filter bed $\left(\mathrm{m}^{3}\right)$ and $C_{\mathrm{i}}$ and $C_{0}$ are the inlet and exit styrene or acetone concentrations $\left(\mathrm{g} \mathrm{m}^{-3}\right)$.

\subsection{Batch tests}

Batch biodegradation tests were conducted using the pure Sporothrix sp., and the Sporothrix-like microorganism present in the leachate of the biofilter, in an attempt to evaluate the removal pattern of styrene and acetone. $50 \mathrm{ml}$ of leachate, collected from the biofilter after transient loading conditions, was centrifuged $(20 \mathrm{~min}, 10,000 \times \mathrm{g}$, $25^{\circ} \mathrm{C}$ ), and the cell-pellets were harvested by several repeated washing with the media. Experiments, with a working volume of $10 \mathrm{ml}$, were carried out at ambient temperature, by constant shaking at $175 \mathrm{rpm}$ under aerobic conditions in $110 \mathrm{ml}$ glass vials fitted with Viton septa and sealed air-tight with aluminum crimps. Liquid styrene and acetone, corresponding to the desired liquid phase concentrations were added to the mineral salt medium. After attaining equilibrium between the head-space and liquid phase concentrations, the cell-pellets ( $3 \% \mathrm{v} / \mathrm{v})$ were suspended, to give similar initial biomass concentrations in the test vial. All batch experiments were carried out in duplicate and the average values were presented. The biodegradation profile was monitored by periodically withdrawing $2 \mathrm{ml}$ of head-space samples and subjecting them to gas chromatograph analysis for residual styrene and acetone concentrations. The concentrations in the liquid-phase was then calculated from Henry's partition coefficient value at $25{ }^{\circ} \mathrm{C}$. The growth of the fungus, monitored as biomass concentration $\left(\mathrm{mg} \mathrm{l}^{-1}\right)$, that was earlier correlated to OD at $600 \mathrm{~nm}$, was estimated by periodically withdrawing $1 \mathrm{ml}$ of sample at different time intervals from the test vial. Head-space samples were also withdrawn periodically for analyzing the $\mathrm{CO}_{2}$ generation rate during the biodegradation process. 


\subsection{Analytical methods}

Styrene and acetone concentrations in gas samples were measured by gas chromatography on an HP 6890 gas chromatograph, using a $50 \mathrm{~m}$ TRACER column and a FID. The flow rates were $30 \mathrm{ml} \mathrm{min}^{-1}$ for $\mathrm{H}_{2}$ and $300 \mathrm{ml} \mathrm{min}^{-1}$ for air. Helium was used as the carrier gas at a flow rate of $2 \mathrm{ml} \mathrm{min}^{-1}$. The temperatures at the GC injection, oven and detection ports were 250,120 and $250{ }^{\circ} \mathrm{C}$ respectively. Typical gas elution times in GC were 7.2 and $2.9 \mathrm{~min}$, respectively for styrene and acetone. $\mathrm{CO}_{2}$ was analyzed with a HP 5890 gas chromatograph, fitted with a Porapak-Q type column and equipped with a TCD. The injection and oven temperatures were 90 and $25^{\circ} \mathrm{C}$, respectively, with the TCD set at $100^{\circ} \mathrm{C}$. For $\mathrm{pH}$ measurements, a Crison $\mathrm{pH}$ meter (Model-507), connected to an Ingold electrode was used. Fungal growth was quantified by measuring the OD, and a standard calibration line was plotted based on the relationship between cell-dry weight and OD. The absorbance $(600 \mathrm{~nm})$ of the liquid cultures, related to the growth of $S$. variecibatus with styrene and acetone as the carbon source, was measured by using a UV-vis spectrophotometer (Hitachi, Model U-200, Pacisa \& Giralt, Madrid, Spain). The relative humidity of the incoming air-pollutant mixture, was monitored periodically using a hand held thermo-hygrometer (ModelC210), fitted with a flexible sampling probe (G. Lufft Mess-und Regeltechnik, GmbH, Germany). Pressure drop across the biofilter was measured using a differential U-tube water manometer connected to the top and bottom sections, with the operational range of $0-40 \mathrm{~cm} \mathrm{H}_{2} \mathrm{O}$.

\section{Results and discussions}

\subsection{Start-up of the biofilter}

The performance of the biofilter was evaluated under steady-state conditions by varying the concentrations of styrene and acetone independently, in four different phases of operation, corresponding to gas-flow rates varying between 0.05 and $0.4 \mathrm{~m}^{3} \mathrm{~h}^{-1}$. The concentration of each individual pollutant, the EBRT and loading rates tested in these four phases are given in Table 1.

Table 1.

Operational phases in the biofilter.

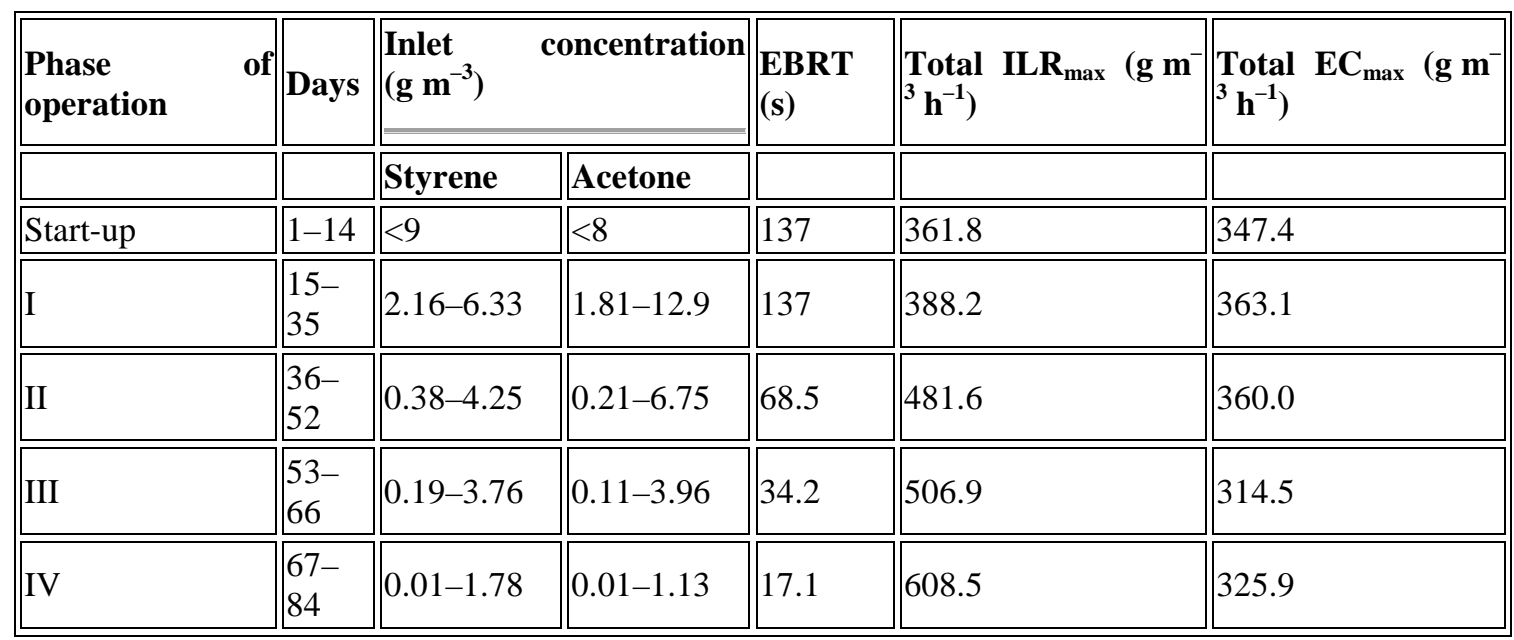


The biofilter was inoculated with acclimated fungal spores of S. variecibatus. During start-up, for the first $3 \mathrm{~d}$, the biofilter was acclimated to low loading rates of both styrene and acetone vapours, $\mathrm{ILR}_{\text {Total }}<50 \mathrm{~g} \mathrm{~m}^{-3} \mathrm{~h}^{-1}$, and more than $82 \%$ removal was noticed for both compounds. Therefore, for the next $11 \mathrm{~d}$, the inlet concentrations of both styrene and acetone were increased, and the biofilter was able to achieve nearly stable RE of $>90 \%$ styrene and $>80 \%$ acetone, when styrene and acetone concentrations were less than 6 and $4 \mathrm{~g} \mathrm{~m}^{-3}$, respectively. These concentration ranges for acclimating the fungal biofilter are quite high, as most biofilters generally use only low concentrations, i.e., less than $0.5 \mathrm{~g} \mathrm{~m}^{-3}$, during acclimation [8]. This was presumably possible because Sporothrix sp. has shown the ability to tolerate high concentrations of styrene $\left(12-14 \mathrm{~g} \mathrm{~m}^{-3}\right)$ [5] and [6] and because acetone, as reported in the literature, is an easily biodegradable compound in both waste-gases and wastewaters [4] and [16]. The relative humidity of the air stream was maintained at $90 \%$ or more, during all the experiments by constantly humidifying the incoming pollutant mixture. This also helped in maintaining the necessary moisture conditions specified for biofilter operation [8]. After the start-up period, experiments were conducted by either increasing and/or decreasing the concentration of styrene and/or acetone, in a systematic manner, at different EBRTs, corresponding to ILR $\mathrm{T}_{\text {Total }}$ varying between 448.9 and $608.5 \mathrm{~g} \mathrm{~m}^{-3} \mathrm{~h}^{-1}$.

\subsection{Performance of the biofilter at different EBRT}

\subsubsection{Phase-I: EBRT of $137 \mathrm{~s}$}

The removal and elimination capacity profiles of both styrene and acetone under different initial concentrations and EBRT, corresponding to four different phases of operation are shown in Fig. 3a-c, respectively. It can be seen that the concentrations of styrene varied between 3.5 and $6 \mathrm{~g} \mathrm{~m}^{-3}$ during the first $5 \mathrm{~d}$ of operation, while the acetone concentration was lowered from $4 \mathrm{~g} \mathrm{~m}^{-3}$ to $2 \mathrm{~g} \mathrm{~m}^{-3}$, resulting in $96 \% \mathrm{RE}$ for styrene and about 90\% RE for acetone in all cases. However, when the acetone concentration was increased from 2 to $6.5 \mathrm{~g} \mathrm{~m}^{-3}$, the RE of acetone dropped, reaching stable values at around $78 \%$. Subsequently, when the concentration of styrene (2.7$5.7 \mathrm{~g} \mathrm{~m}^{-3}$ ) and acetone (2.3-5.8 $\mathrm{g} \mathrm{m}^{-3}$ ) were maintained between these values from day 28-35, RE > 92\% was achieved for styrene, while RE for acetone varied between 67 and $91 \%$. During this phase, the biofilter was subjected to styrene and acetone loading rates varying between 56.8 and $166.5 \mathrm{~g} \mathrm{~m}^{-3} \mathrm{~h}^{-1}$ and 47.6 and $234.5 \mathrm{~g} \mathrm{~m}^{-3} \mathrm{~h}^{-1}$, respectively. As seen from Fig. $4 \mathrm{a}$ and b, maximum ECs of $163 \mathrm{~g} \mathrm{~m}^{-3} \mathrm{~h}^{-1}$ and $151 \mathrm{~g} \mathrm{~m}^{-}$ ${ }^{3} \mathrm{~h}^{-1}$ were observed for styrene and acetone, respectively. From these figures, it is also evident that, the EC increased linearly with an increase in the loading rates for both pollutants, but as far as acetone profiles are concerned, these profiles were not linear after a critical loading rate. However, for styrene, the linear relationship between loading rate and EC with a slope of 1 under the tested experimental conditions, i.e., maximum ILR for styrene of $166.5 \mathrm{~g} \mathrm{~m}^{-3} \mathrm{~h}^{-1}$, indicates that a maximum overall elimination capacity was not reached at an EBRT of $137 \mathrm{~s}$, and that styrene loading rates could still be increased in the fungal biofilter. ECs exceeding such value of $166.5 \mathrm{~g} \mathrm{~m}^{-3} \mathrm{~h}^{-1}$ would then be possible. 

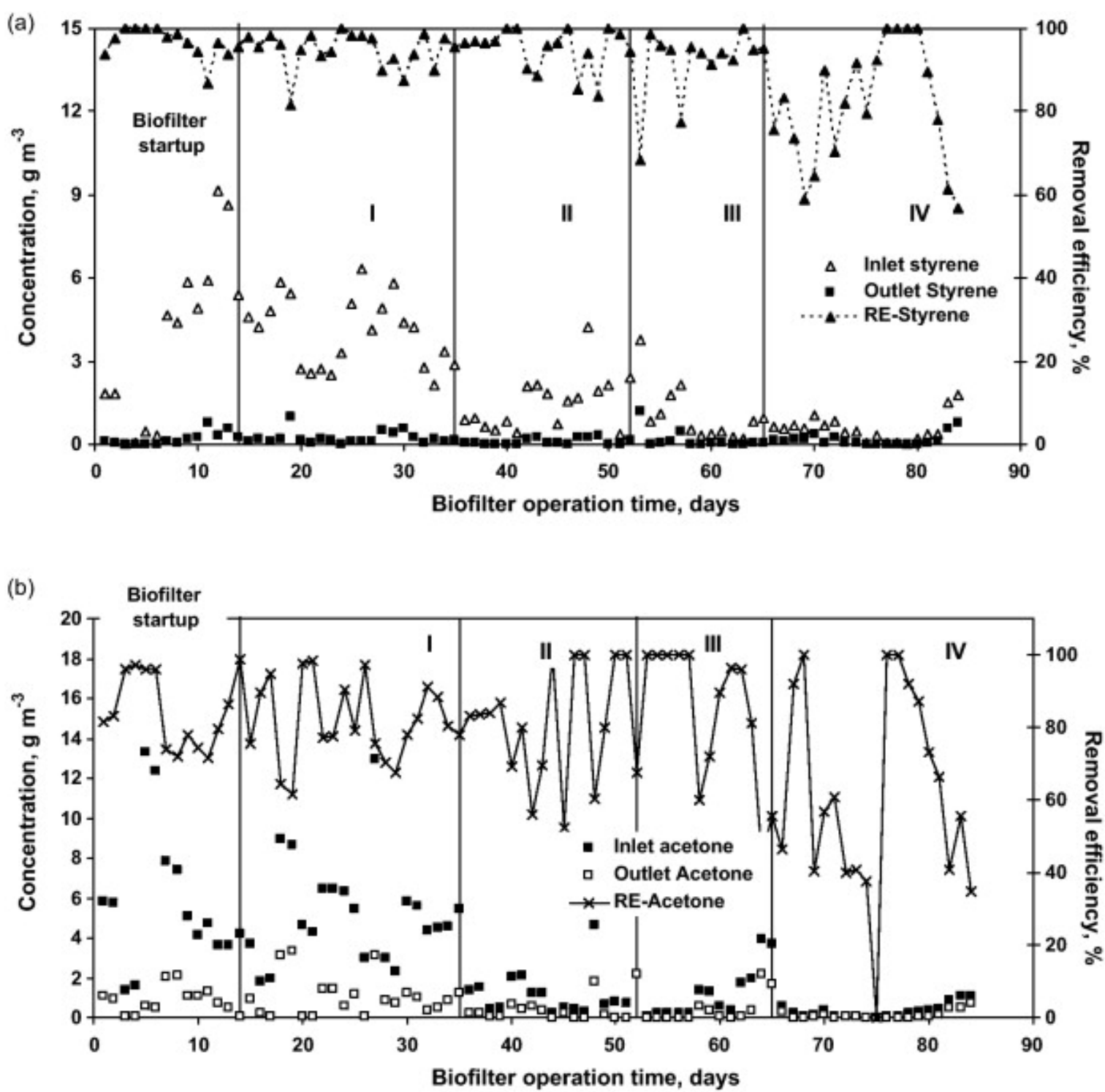

(c)

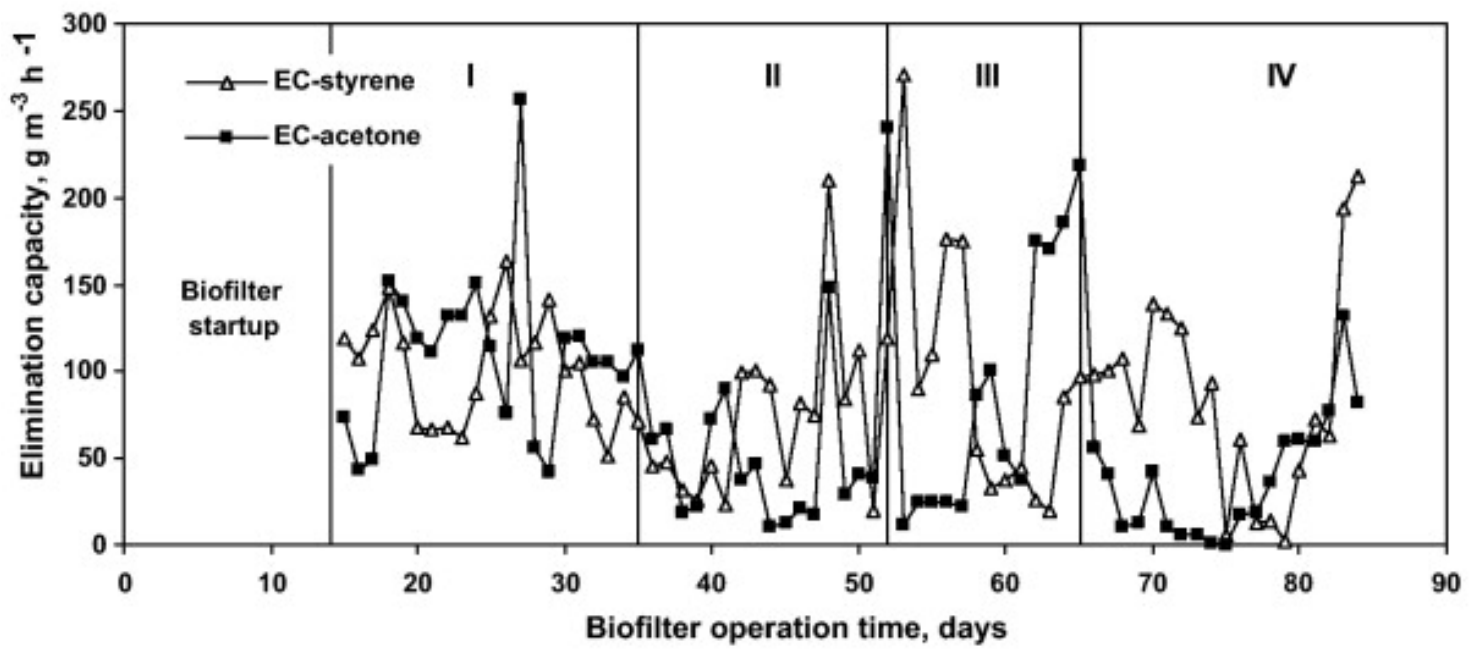

Fig. 3.

Profiles of (a) styrene removal, (b) acetone removal, and (c) elimination capacity of the fungal biofilter during different phases of biofilter operation. 

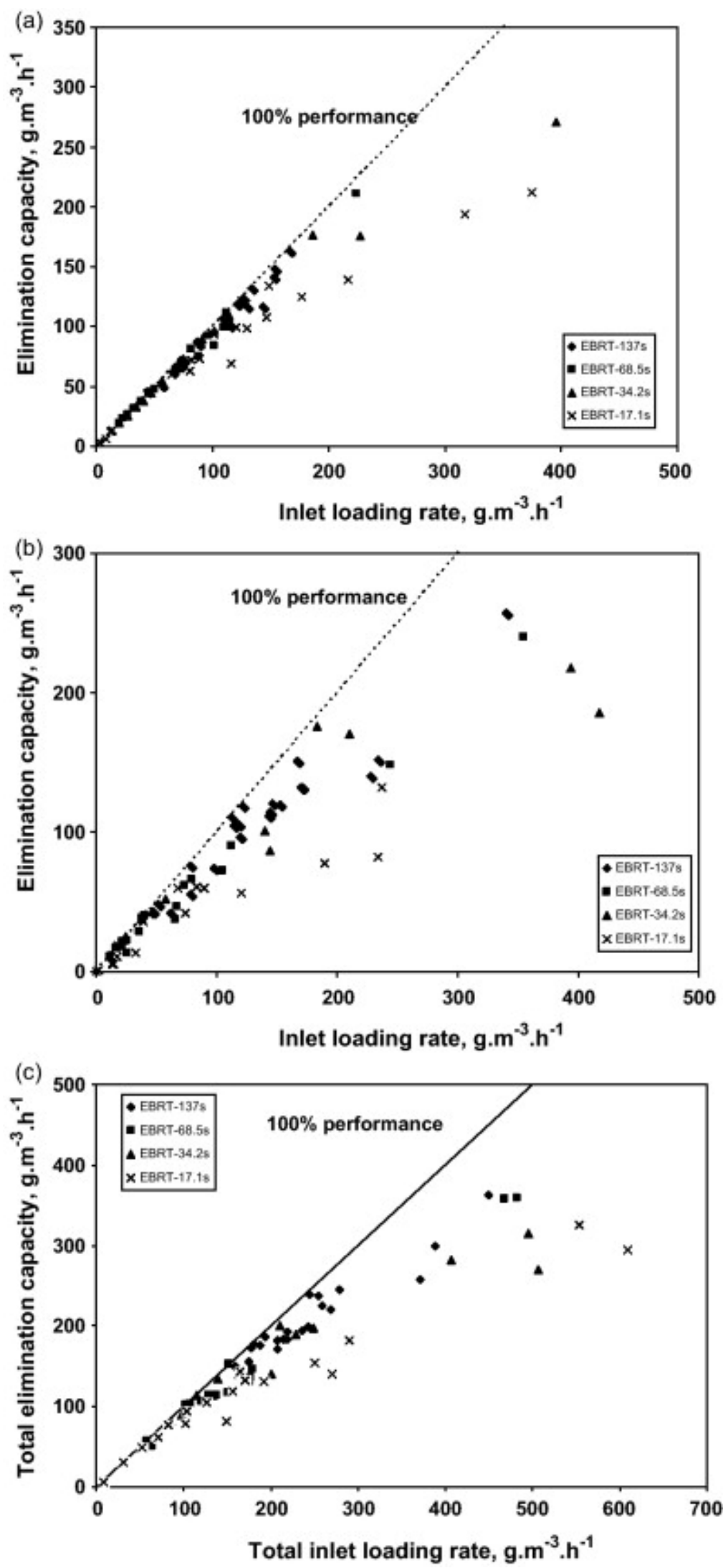

Fig. 4.

Profiles of inlet loading rate vs. elimination capacity at different EBRTs, (a) styrene, (b) acetone, and (c) total pollutant load. 


\subsubsection{Phase-II: EBRT of $68.5 \mathrm{~s}$}

In this phase (days 36-52), the concentrations of both styrene and acetone were reduced in comparison to Phase-I, and varied between 0.38 and $4.25 \mathrm{~g}$ styrene $\mathrm{m}^{-3}$ and 0.21 and $6.8 \mathrm{~g}$ acetone $\mathrm{m}^{-3}$, respectively (Fig. 3). By doing so, it was observed that, low concentrations of styrene led to high RE ( $>85 \%)$ of that compound, irrespective of the concentration of acetone in the gas-phase mixture. For instance, during days 36-41, when styrene concentration was less than $1 \mathrm{~g} \mathrm{~m}^{-3}$, and when acetone concentrations were varied between 0.4 and $2.1 \mathrm{~g} \mathrm{~m}^{-3}$, styrene $\mathrm{RE}>96 \%$ was easily maintained in the biofilter, while increasing the acetone concentration in that concentration range decreased the acetone RE from $90 \%$ to nearly $70 \%$. This trend clearly indicates that the system would suffer from some interactive effects among these pollutants, leading to a decreased performance to a certain level, depending on the individual pollutant concentration and the gas-flow rate. Nevertheless, though the system readapted quickly to changes in loading rates during this phase, an increase in pollutant load did not lead to any drastic performance drop, and the RE for styrene and acetone did not drop below $85 \%$ and $60 \%$ during this phase. The ILR varied between 20 and $224 \mathrm{~g}$ styrene $\mathrm{m}^{-3} \mathrm{~h}^{-1}$ and 11 and $355 \mathrm{~g}$ acetone $\mathrm{m}^{-3} \mathrm{~h}^{-1}$, and $\mathrm{EC}_{\max }$ of 210 and $148 \mathrm{~g} \mathrm{~m}^{-3} \mathrm{~h}^{-1}$ were achieved for styrene and acetone, respectively (Fig. 4a and b). Higher EC could have been reached for styrene since the critical load was not reached in this experiment.

\subsubsection{Phase-III: EBRT of $34.2 \mathrm{~s}$}

During days 53-65, the biofilter was subjected to a much lower residence time (34.2 s), and the inlet styrene and acetone concentrations were also maintained low for most part of the experiment $\left(<1 \mathrm{~g} \mathrm{~m}^{-3}\right)$, although on certain occasions, they were increased up to about $4 \mathrm{~g} \mathrm{~m}^{-3}$, to identify the interaction effects at high concentration of one pollutant on the other. As seen from Fig. 3, when the concentrations of both pollutants were relatively low in Phase-III, i.e., less than $0.5 \mathrm{~g} \mathrm{~m}^{-3}$, REs were greater than $90 \%$ for both styrene and acetone. This indicates that the biofilter was subjected to loads that were

less than the critical loading rate to achieve more than 90\% RE. On the other hand, low concentrations of acetone and moderately high concentrations of styrene $\left(2.2 \mathrm{~g} \mathrm{~m}^{-3}\right)$, did not affect acetone removal much. However, the reverse occurred when the biofilter was fed low concentrations of styrene and moderately high concentrations of acetone (3.5$4 \mathrm{~g} \mathrm{~m}^{-3}$ ). The removal of acetone reduced significantly and varied between 45 and 55\%. At this residence time, increasing acetone concentrations, by holding styrene levels at constant values, appeared to have a drastic effect on its own removal. The $\mathrm{EC}_{\max }$ at this EBRT were nearly $170 \mathrm{~g} \mathrm{~m}^{-3} \mathrm{~h}^{-1}$ for both styrene and acetone (Fig. 4a and b) with RE of about $90 \%$ and $85 \%$, respectively.

\subsubsection{Phase-IV: EBRT of 17.1 s}

Phase-IV, corresponding to the lowest EBRT tested in this study, i.e., $17.1 \mathrm{~s}$, was investigated at relatively low concentrations of the compounds, corresponding to ILR varying between up to $374 \mathrm{~g} \mathrm{~m}^{-3} \mathrm{~h}^{-1}$ for styrene and $237 \mathrm{~g} \mathrm{~m}^{-3} \mathrm{~h}^{-1}$ for acetone. Once again, the performance of the system depended on the concentration of these two compounds in mixture. For styrene and acetone concentrations less than 0.8 and $0.3 \mathrm{~g} \mathrm{~m}^{-3}$, nearly $80 \%$ styrene and $70 \%$ acetone was removed in the biofilter. However, for some days, when the concentrations of these two compounds were increased, thereby increasing the $I_{L R}$ Total to the biofilter, an abrupt decline in the RE of both the 
compounds was noticed. For instance, for styrene concentrations $>1.7 \mathrm{~g} \mathrm{~m}^{-3}$ and acetone concentration $>1 \mathrm{~g} \mathrm{~m}^{-3}$, their RE were just $56 \%$ and $34 \%$, respectively. During this phase, the biofilter was tested for styrene and acetone ILR up to $374 \mathrm{~g} \mathrm{~m}^{-3} \mathrm{~h}^{-1}$ and $237 \mathrm{~g} \mathrm{~m}^{-3} \mathrm{~h}^{-1}$, while their $\mathrm{EC}_{\max }$ values were $212 \mathrm{~g} \mathrm{~m}^{-3} \mathrm{~h}^{-1}$ and $82 \mathrm{~g} \mathrm{~m}^{-3} \mathrm{~h}^{-1}$ (Fig. $4 \mathrm{a}$ and b). At this EBRT, the total maximum EC achieved was $326 \mathrm{~g} \mathrm{~m}^{-3} \mathrm{~h}^{-1}$ at an ILR Total of $554 \mathrm{~g} \mathrm{~m}^{-3} \mathrm{~h}^{-1}$, which corresponds to about $41.2 \%$ removal of the total pollutant load (Fig. 4c).

\subsubsection{Maximum EC of the biofilter}

The maximum EC for styrene was $212 \mathrm{~g} \mathrm{~m}^{-3} \mathrm{~h}^{-1}$ with $58 \%$ removal, at an EBRT of $17.1 \mathrm{~s}$ and when acetone loads were comparatively low in mixture $\left(235 \mathrm{~g} \mathrm{~m}^{-3} \mathrm{~h}^{-1}\right)$. On the other hand, $\mathrm{EC}_{\max }$ for acetone was $151 \mathrm{~g} \mathrm{~m}^{-3} \mathrm{~h}^{-1}$, at an EBRT of $137 \mathrm{~s}$, when styrene ILR was $87 \mathrm{~g} \mathrm{~m}^{-3} \mathrm{~h}^{-1}$. Some of the higher EC values observed for both styrene and acetone under non-anticipated peak load condition (S: $270 \mathrm{~g} \mathrm{~m}^{-3} \mathrm{~h}^{-1}$ and $\mathrm{A}$ : $257 \mathrm{~g} \mathrm{~m}^{-3} \mathrm{~h}^{-1}$ ), were not considered to be steady-state (Fig. 4a and b). As mentioned earlier, and from Fig. 4a and b, it is quite evident that the EC for styrene could have been still higher if the biofilter was fed with higher loads of styrene, at an EBRT of 137 and $68.5 \mathrm{~s}$, while that was obviously not the case for acetone, which clearly shows the existence of a critical load at these EBRTs. This clearly indicates that the Sporothrix sp., isolated from a styrene operated biofilter [5] has the ability to achieve higher ECs for styrene, although the biofilter was co-supplied with varying loads of acetone. Nevertheless, the fungal biofilter performance, in terms of the maximum EC for acetone, decreased significantly when the EBRT was decreased from $34.2 \mathrm{~s}$ to $17.1 \mathrm{~s}$, though such a difference in the $\mathrm{EC}_{\max }$ values were not observed at higher EBRTs, i.e., $68.5 \mathrm{~s}$ and $137 \mathrm{~s}$. At the lowest EBRT, i.e., $17.1 \mathrm{~s}$, the fungus gets less contact time for the degradation of gas-phase styrene and acetone, resulting in reduced biofilter performance. Usually, it has been observed in BFs that the $\mathrm{EC}$ or $\mathrm{EC}_{\max }$ decreases when increasing the gas flow rate or space velocity, i.e., decreasing the EBRT [14], [17] and [18].

The $\mathrm{pH}$ of the leachate occasionally dropped to values ranging between 2.3 and 4.7, depending on the $\operatorname{ILR}_{\text {Total }}$ to the biofilter. On days 48, 64-66 and 82-84, when the $I_{L R}$ Total was greater than $400 \mathrm{~g} \mathrm{~m}^{-3} \mathrm{~h}^{-1}$, the EC of the fungal biofilter was greater than $300 \mathrm{~g} \mathrm{~m}^{-3} \mathrm{~h}^{-1}$, despite the variation in $\mathrm{pH}$ values between 2.3 and 2.9. Besides, the periodic sprinkling of nutrient medium from the top helped to maintain the biological activity of the fungus, even though the $\mathrm{pH}$ dropped occasionally. The pressure drop values were less than $1.3 \mathrm{~cm} \mathrm{H}_{2} \mathrm{O}$ during the entire experimental period. In comparison, these values of pressure drop are somewhat lower than the values reported in literature for a mixed culture inoculated biofilter $\left(0.5-4.2 \mathrm{~cm} \mathrm{H}_{2} \mathrm{O}\right)$ and a fungal biofilter $(3 \mathrm{~cm}$ $\mathrm{H}_{2} \mathrm{O}$ ) treating gas-phase styrene [5] and [6].

\subsection{Pollutant interactions}

During the treatment of gas-phase mixtures, synergistic and/or antagonistic effects may appear. In this study, at a given EBRT, the following interactions were observed: (i) low concentrations of both pollutants did not affect their removal and RE $>90 \%$ was easily maintained, (ii) styrene concentrations $<1 \mathrm{~g} \mathrm{~m}^{-3}$, and moderately high concentrations of acetone around $2 \mathrm{~g} \mathrm{~m}^{-3}$ affected acetone removal by $20 \%$, while styrene $\mathrm{RE}$ was $>96 \%$, (iii) low concentrations of acetone and a high concentration of styrene $\left(4 \mathrm{~g} \mathrm{~m}^{-3}\right)$ did not 
affect styrene nor acetone removal, and (iv) high concentrations of both acetone and styrene $\left(>4.5 \mathrm{~g} \mathrm{~m}^{-3}\right)$ affected acetone removal more severely than styrene that was affected only slightly (2-6\%). A recent short study shed more light on the type of interactions observed in a bacterial biofilter, during the co-treatment of styrene and acetone [19]. In that study, the concentration of gas-phase styrene was kept constant (50 $\mathrm{mg} \mathrm{m}^{-3}$ ), while acetone concentration was increased from 47 to $1057 \mathrm{mg} \mathrm{m}^{-3}$, and it was reported that, the varying concentrations of acetone not only affected its own removal, but also that of styrene. In some cases, the removal of one compound in mixture consistently remains unaffected despite the varying concentration levels of the other compound. In a study involving methanol and toluene as the co-substrate, it has been reported that toluene produced higher inhibitory effects than methanol in a biofilter, and that toluene, a non-polar compound, could easily be transported across the hydrophobic cell membrane and is able to leak essential metabolites and co-factors that could kill the cells [20].

\subsection{Substrate stratification along the bed height}

The dynamics of pollutant removal along the bed height was envisaged by measuring the concentration profiles at different bed depths, during Phase-I, and Phase-IV (Fig. 5 a and $b$ ). The inlet concentrations of styrene and acetone during these experiments were as follows; $6.4,5.8 \mathrm{~g} \mathrm{~m}^{-3}$ and $1.02,1.28 \mathrm{~g} \mathrm{~m}^{-3}$, corresponding to ILR of 169.2 and $215.5 \mathrm{~g}$ styrene $\mathrm{m}^{-3} \mathrm{~h}^{-1}$ and 153.2 and $269.4 \mathrm{~g}$ acetone $\mathrm{m}^{-3} \mathrm{~h}^{-1}$, respectively. It can be observed that, substrate stratification occurred in terms of styrene and acetone removal. At low gas-flow rates, i.e., Phase-I, acetone removal was almost linear across the filter bed, the first half of the filter bed $(23.5 \mathrm{~cm})$ removed nearly $40 \%$ and the later half $(26 \mathrm{~cm}$ ) removed $40 \%$ of gas-phase acetone. However, 30\% styrene was removed in the first half of the filter bed, while $60 \%$ was removed in the later half. During phase-IV (EBRT-17.1 s) and at low inlet concentrations of these pollutants $\left(<1.3 \mathrm{~g} \mathrm{~m}^{-3}\right.$, high ILR), a major fraction of the styrene and acetone removed (74\% and $66 \%$ ), occurred in the lower half of the filter bed, while the first $23.5 \mathrm{~cm}$ removed only about $37 \%$ styrene and $22 \%$ acetone. These profiles suggest that the filter bed was colonized completely with the fungal population, and it was able to utilize styrene and acetone simultaneously. Besides, at higher loading rates (Phase-IV), a major portion of the biodegradation occurred in the lower half of the filter bed (ILR $\mathrm{Total}-484.9 \mathrm{~g} \mathrm{~m}^{-3} \mathrm{~h}^{-1}$ ). From Fig. 5a, it is also evident that high concentrations of acetone and styrene to the biofilter affected acetone removal more severely than styrene removal. 

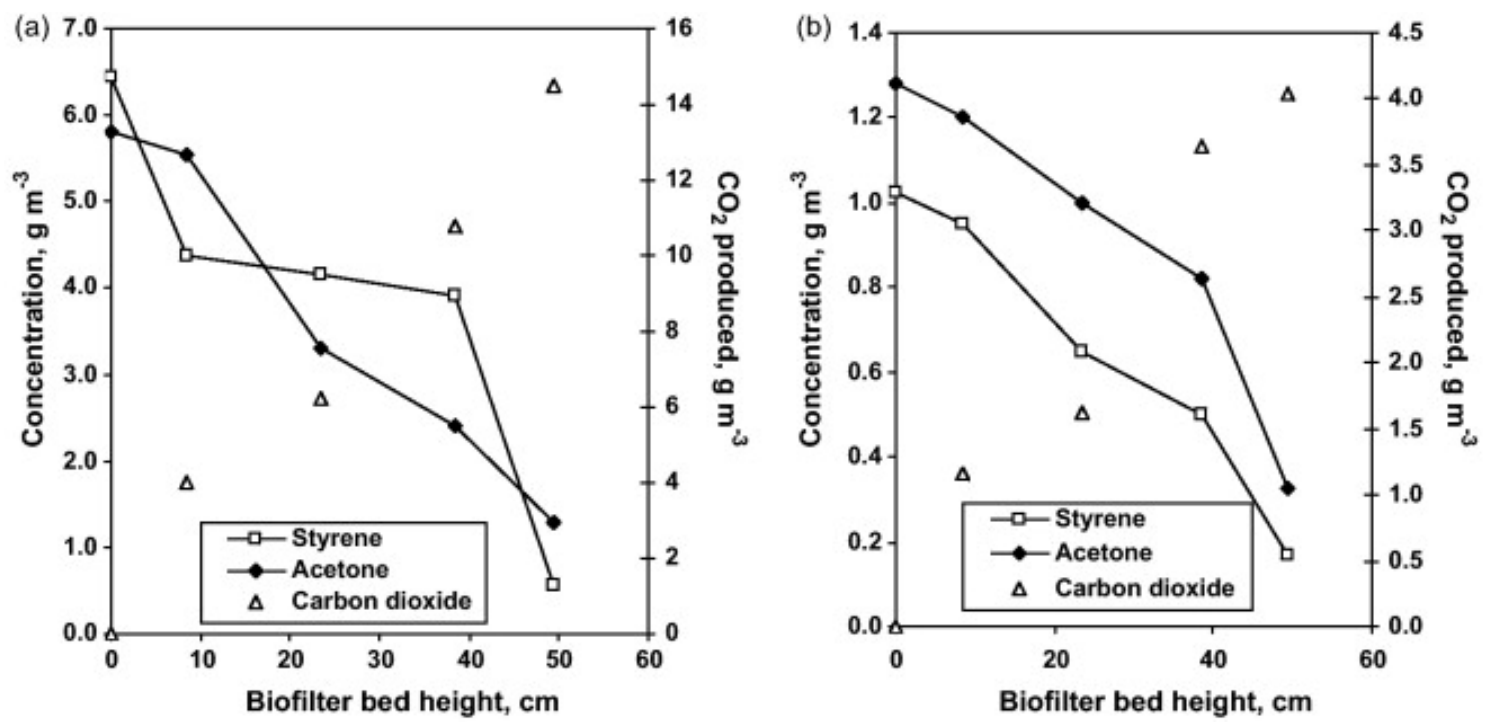

Fig. 5.

Styrene, acetone and carbon dioxide concentration profiles along the biofilter height; (a) EBRT: $137 \mathrm{~s}$; CS: $6.4 \mathrm{~g} \mathrm{~m}^{-3}$; CA: $5.8 \mathrm{~g} \mathrm{~m}^{-3}$; and (b) EBRT: $17.1 \mathrm{~s}$; CS: $1.02 \mathrm{~g} \mathrm{~m}^{-3}$; CA: $1.28 \mathrm{~g} \mathrm{~m}^{-3}$.

Perlite samples were intermittently removed through the gas-sampling ports and periodically examined under an optical microscope, in order to confirm the presence of the original fungus in the biofilter. The cells on the perlite samples clearly looked like the original Sporothrix sp. based on its morphological characteristics. Several reports on bacterial or mixed culture biofilters have also reported substrate stratification along the bed height, during the treatment of two or more gas-phase pollutants. Ergas et al. [21] studied toluene and DCM removal in a biofilter and observed that, toluene removal occurred in the top section of the filter bed, while DCM removal mainly occurred in the lower section, and this stratification was attributed to the possible presence of two different microbial communities within the filter bed, each one having preference for one compound over the other. Also, it has been well-established that, in biofilters treating mixture of VOCs, specific microorganisms have the ability to preferentially choose and degrade the less toxic compound rather than the ones that are more toxic and inhibitory to its growth. Similarly, concentration profiles in a biofilter inoculated with the fungus Cladosporium sphaerospermum treating a complex mixture of MPK, MEK, toluene and $n$-butyl acetate, showed that the removal profiles of these compounds differed largely depending on the substrate utilization potential of that fungus. In that study, $n$-butyl acetate was readily removed followed by MEK, MPK and toluene [22].

\subsection{Carbon dioxide evolution in the biofilter}

During these experiments, carbon dioxide concentrations were also monitored along the bed height, by calculating the difference between the inlet and outlet $\mathrm{CO}_{2}$ concentrations (secondary ' $y$-axis' in Fig. $5 \mathrm{a}$ and b). For complete oxidation of styrene and acetone to $\mathrm{CO}_{2}$ and water [23], the mass-ratio of $\mathrm{CO}_{2}$ produced to the amount of styrene and/or acetone degraded should be 3.4 and 2.3, according to the following stoichiometric reaction (Eqs. (6) and (7)):

$\mathrm{C}_{8} \mathrm{H}_{8}+10 \mathrm{O}_{2} \rightarrow 8 \mathrm{CO}_{2}+4 \mathrm{H}_{2} \mathrm{O}$

$\mathrm{C}_{3} \mathrm{H}_{6} \mathrm{O}+4 \mathrm{O}_{2} \rightarrow 3 \mathrm{CO}_{2}+3 \mathrm{H}_{2} \mathrm{O}$ 
However, when biomass growth is taken into account with ammonium chloride as nitrogen source, $1.27 \mathrm{~g} \mathrm{CO}_{2}$ should be generated per g styrene degraded, while $0.378 \mathrm{~g}$ $\mathrm{CO}_{2}$ should be produced for $1 \mathrm{~g}$ acetone degraded, and the stoichiometric equations can be written as follows (Eqs. (8) and (9));

equation(8)

$\mathrm{C}_{8} \mathrm{H}_{8}+5 \mathrm{O}_{2}+\mathrm{NH}_{4} \mathrm{Cl} \rightarrow 3 \mathrm{CO}_{2}+\mathrm{C}_{5} \mathrm{H}_{7} \mathrm{NO}_{2}+\mathrm{HCl}+2 \mathrm{H}_{2} \mathrm{O}$

equation(9)

$2 \mathrm{C}_{3} \mathrm{H}_{6} \mathrm{O}+3 \mathrm{O}_{2}+\mathrm{NH}_{4} \mathrm{Cl} \rightarrow \mathrm{CO}_{2}+\mathrm{C}_{5} \mathrm{H}_{7} \mathrm{NO}_{2}+\mathrm{HCl}+4 \mathrm{H}_{2} \mathrm{O}$

In this study, the ratio of $\mathrm{CO}_{2}$ produced to the amount of pollutant that was collectively removed in the biofilter, was less than the theoretical amount of $\mathrm{CO}_{2}$ that was expected to be produced in the biofilter, i.e., $1.648 \mathrm{~g} \mathrm{CO}_{2}$ should theoretically be produced for every one $g$ styrene and one $g$ acetone that is simultaneously removed in the fungal biofilter. In this study, 6.4 and $5.8 \mathrm{~g} \mathrm{~m}^{-3}$ of styrene and acetone was fed to the biofilter during Phase-I (EBRT-137 s), and RE greater than 80\% was noticed for both compounds. Discrepancies between theoretical and observed $\mathrm{CO}_{2}$ profiles are common and have often been reported in biofilters, both fungal and bacterial populations, especially when subjected to high loads of individual or mixtures of gas-phase pollutants. Woertz et al. [24] reported $\mathrm{CO}_{2}$ recoveries around $57 \%$ for Exophiala leccanii-corni grown on toluene. Cox et al. [25] reported $\mathrm{CO}_{2}$ recoveries ranging from 40 to $100 \%$ over a $300 \mathrm{~d}$ period for styrene removal using the fungus Exophiala jeanselmei. Besides, $\mathrm{CO}_{2}$ production exceeding $100 \%$ is also not unusual in biofilters when endogenous respiration becomes a relevant process.

\subsection{Transient-state response of the biofilter}

Non-steady state or transient operations in a biofilter are frequently encountered in the form of a sudden pollutant shock-loads, and/or as unexpected shut-down of the system. Since biofilters include the presence of active microorganisms, they are sensitive to these sudden variations, i.e., flow rate or concentration or a combination of both at once, and the absence of gas-phase pollutant during shut-down. The microorganisms could sustain sudden, yet medium shock loads well, but high shock loads are harder to tolerate over a long period of time, especially for hydrophobic VOCs [5] and [13]. Though such operations have been stimulated under lab conditions in many previously reported studies, most of them address the biofilter response for individual hydrophobic or hydrophilic compounds. Only a few papers have mentioned the events associated with mixtures of two or more pollutants, especially in mixed-culture or bacteria - inoculated biofilters [26], [27] and [28], while fungal biofilter response to handle transient shockloads has been reported for $\alpha$-pinene removal [14]. During this experimental phase, the fungal biofilter was subjected to a short term-12 h shock load by suddenly increasing the concentrations from 0.9 to $1.7 \mathrm{~g} \mathrm{~m}^{-3}$ for styrene and from 0.1 to $1 \mathrm{~g} \mathrm{~m}^{-3}$ for acetone, respectively, while maintaining the gas-flow rate constant at $0.4 \mathrm{~m}^{3} \mathrm{~h}^{-1}$, i.e., at an EBRT of $17.1 \mathrm{~s}$. The onset of shock-loads was the 4th hour after taking measurements in the biofilter, that was stabilized overnight and subjected to low pollutant concentrations. The response of the fungal biofilter is shown in Fig. 6. It can be seen that, the RE of both styrene and acetone dropped, from nearly 90 to 100\% before the shock, to about $70 \%$ when their concentrations were increased suddenly. Though their concentrations were low during the shock loading step, high gas-flow rates imparted high loading rates of these pollutants to the biofilter, viz. as $360 \mathrm{~g}$ styrene $\mathrm{m}^{3} \mathrm{~h}^{-1}$ and $240 \mathrm{~g}$ acetone $\mathrm{m}^{3} \mathrm{~h}^{-1}$. Though the removal efficiencies of individual compounds dropped during the shock load, the fungal biofilter was able to withstand an $I_{L R}$ Total of up to $647 \mathrm{~g} \mathrm{~m}^{-3} \mathrm{~h}^{-1}$, 
showing $\mathrm{EC}_{\text {Total }}$ as high as $360 \mathrm{~g} \mathrm{~m}^{-3} \mathrm{~h}^{-1}$ (Fig. 6-inset). Anew, after the shock load and when the concentrations of styrene and acetone were brought down to previously applied low values, the biofilter showed good tendency to recover and reached stable $\mathrm{RE}$ almost instantaneously. In a previous study, a fungus belonging to the Ophiostoma sp. was shown to withstand periodic shock loads of gas-phase $\alpha$-pinene for more than one month of transient-state operations, where EC and RE were found to be $60 \mathrm{~g} \mathrm{~m}^{-3} \mathrm{~h}^{-1}$ and $>90 \%$ respectively. Besides, the biofilter recovery time was less than $4 \mathrm{~h}$ and the fungus showed good activity despite being supplied with high shock-loads [14]. The results from this study suggest that the Sporothrix sp. was able to maintain its cells in an active state and has the ability to develop its own survival strategy during transient-state conditions.
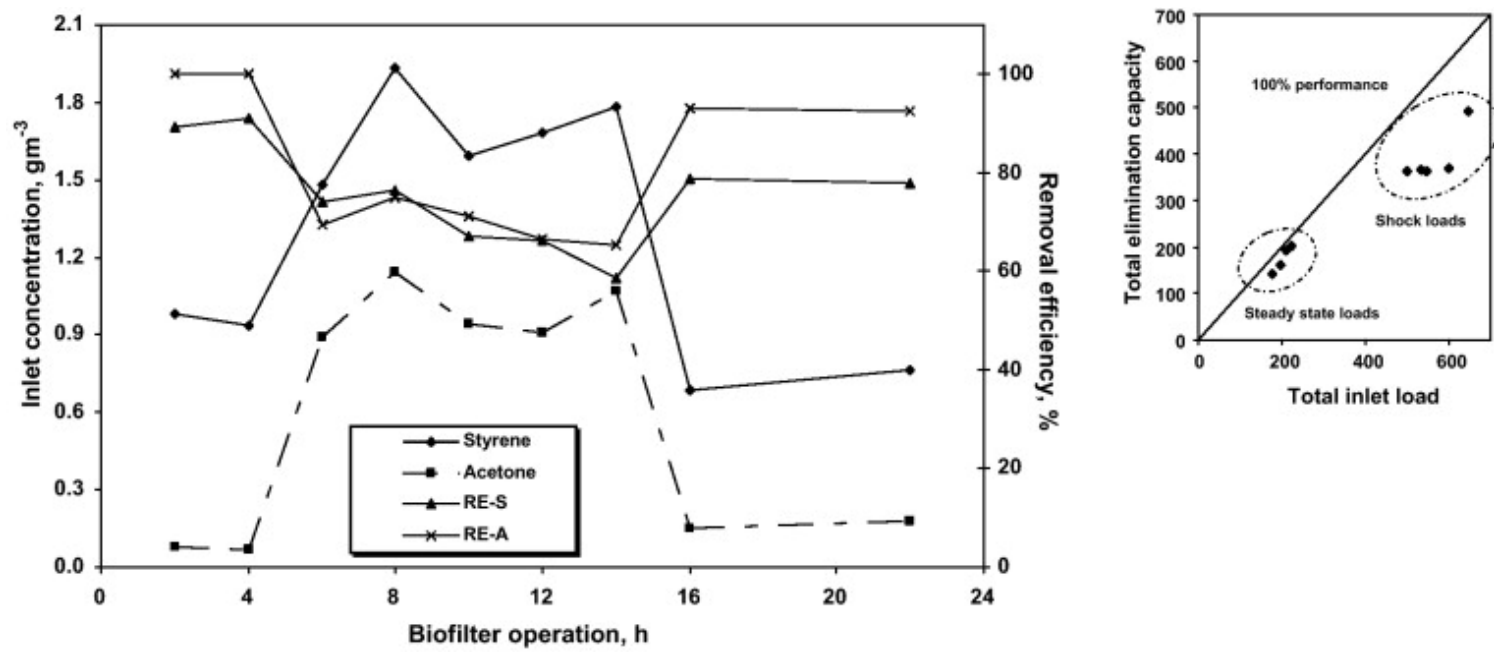

Fig. 6.

Transient response of the fungal biofilter to changes in concentration of both styrene and acetone and total inlet load vs. total elimination capacity $\left(\mathrm{g} \mathrm{m}^{-3} \mathrm{~h}^{-1}\right.$ ) profiles during short-term shock loads (inset), RE-Removal efficiency, SStyrene and A-acetone.

\subsection{Batch confirmation tests for styrene and acetone removal}

After the completion of steady and transient-state biofilter experiments, four sets of batch experiments were carried out by using the leachate-borne Sporothrix sp., viz., in vials with styrene, vials with acetone and vials with mixtures of styrene and acetone. Besides, two additional vials inoculated with the pure Sporothrix sp., were also tested at different initial concentrations of styrene and acetone as mixtures. The objective of this test was to check whether the microbes were able to mineralize styrene and acetone completely, as well as to observe the pattern of complete removal during the cotreatment of mixtures. It is known that interactions may appear in the biodegradation process when several pollutants are present simultaneously [9], [10], [11], [12] and [29] The results illustrated in Fig. 7a-f, show the biodegradation profiles of styrene and acetone, as individual compounds ( Fig. 7(a) and (b)), as mixtures ( Fig. 7(c) and (d)) in leachate inoculated vials, while Fig. 7(e) and (f) show the biodegradation profile of styrene and acetone as mixtures in the pure culture inoculated vials. From these profiles, it is evident that, biomass growth occurred almost instantaneously, followed by steady utilization of the substrate. When $2.411 \mathrm{mg}$ acetone was added to the test vial (liquid phase concentration of $235 \mathrm{mg} \mathrm{l}^{-1}$ ), complete mineralization occurred in about $84 \mathrm{~h}$ by 
the mixed culture (leachate), while $2.607 \mathrm{mg}$ styrene (concentration-105 mg l $\mathrm{l}^{-1}$ ) was removed completely in $235 \mathrm{~h}$ ( Fig. 7b). Biomass growth and $\mathrm{CO}_{2}$ generation profiles were also constantly monitored during the experiments, and by comparing Fig. 7(a) and (b), it was observed that biomass growth was higher during styrene degradation than with acetone.
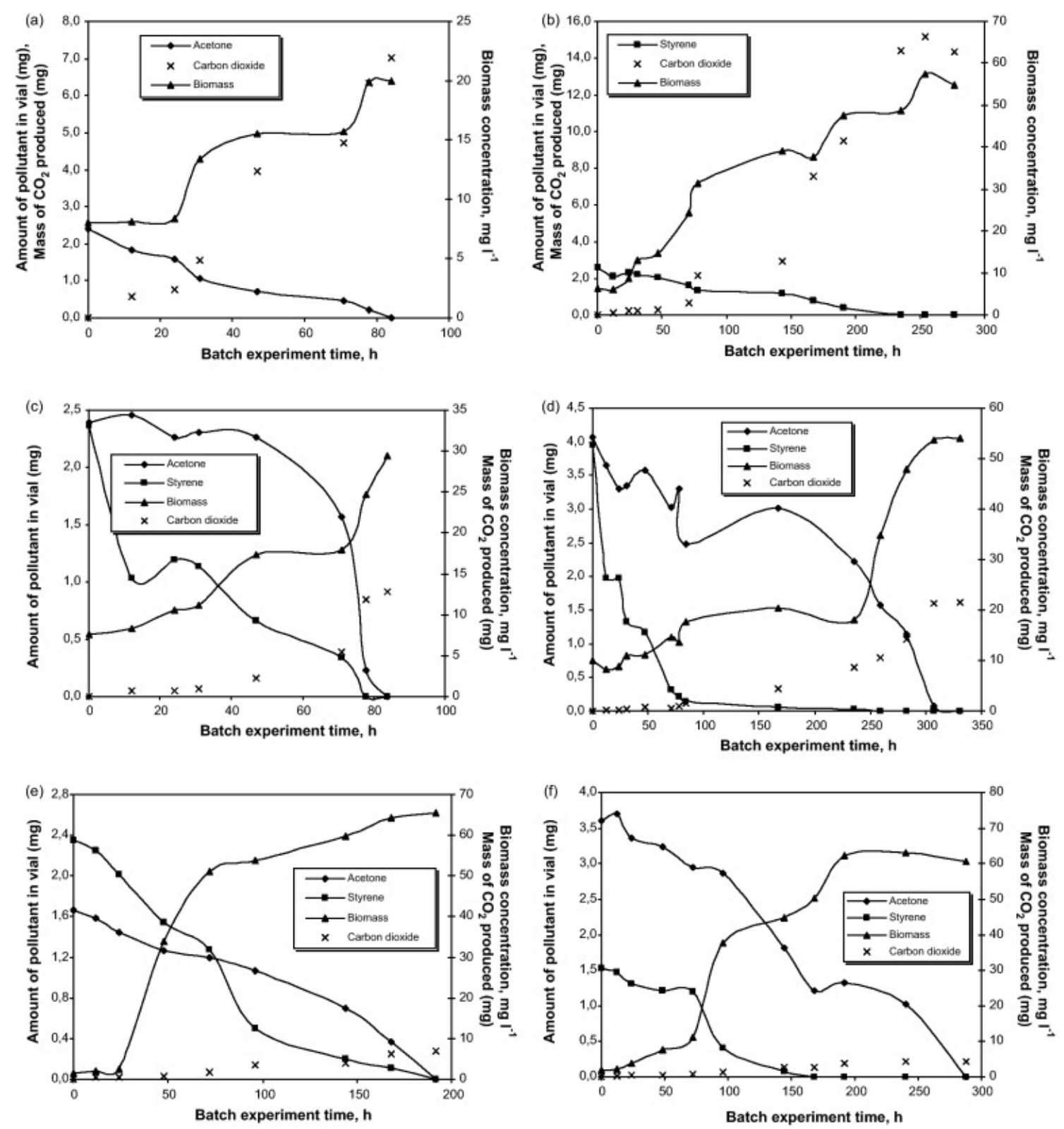

Fig. 7.

Biodegradation, biomass growth and $\mathrm{CO}_{2}$ generation profile in batch test vials inoculated with Sporothrix sp., present in the leachate; (a)acetone alone, (b) styrene alone, (c and d)mixtures of styrene and acetone, and (e and f)styrene and acetone removal profiles by the pure strain of Sporothrix sp.

The biodegradation profile of these two compounds, when present as mixtures is shown in Fig. 7(c) and (d). It can clearly be seen that, though both compounds were utilized by the microorganisms, they definitely had different biodegradation rates, indicating possible chances of preferential utilization of the fungus. When low amounts of styrene 
and acetone were present (S-2.367 mg, and A-2.393 $\mathrm{mg}$ in mixture), both compounds were removed completely in less than $84 \mathrm{~h}$ (Fig. 7c), compared to the longer times taken for their degradation at high initial concentrations (3.949 $\mathrm{mg}$ styrene and $4.072 \mathrm{mg}$ acetone, Fig. 7d). However, in both these cases, biodegradation of styrene occurred faster than acetone, and acetone degradation rates were higher when styrene was not present in the test vial, 4.63 and $4.2 \mathrm{mg}$ acetone mg biomass ${ }^{-1} \mathrm{~h}^{-1}$, respectively. Irrespective of the initial concentrations, it seems that acetone biodegradation takes place mainly after or at the end of styrene removal (Fig. 7(c) and (d)). Similarly, when the pure strain was tested at two different initial concentrations of styrene and acetone as mixtures (S - $2.348 \mathrm{mg}$ and A - $1.663 \mathrm{mg}$ and S - $1.527 \mathrm{mg}$ and A - $3.6 \mathrm{mg}$ ), the removal of styrene occurred more rapidly $(<192 \mathrm{~h})$ than for acetone and acetone started being removed at a faster rate only when styrene was completely depleted in the test vial (Fig. 7(e) and (f)). The $\mathrm{pH}$ of the medium also dropped from an initial value of 5.9 to 4.5 and 3.7 in the mixture vials (Fig. 7(c) and (d)), due to the formation of acidic intermediates like $\mathrm{HCl}$ during the biodegradation process (Eqs. (8) and (9)). The results of these simple tests confirm the fact that Sporothrix sp. can degrade both styrene and acetone. It showed preferential utilization of styrene and corroborates the high removals, $>60 \%$ in all four phases of operation, noticed in the biofilter for that compound. Nevertheless, further batch studies using the pure strain of S. variecibatus are warranted at different process conditions, i.e., different initial concentrations of styrene and acetone, $\mathrm{pH}$, temperature and nutrient concentrations, to constitute the kinetics of the process and estimate different bio-kinetic parameters like maximum specific growth rate, half-velocity and inhibition constants and specific substrate utilization rate.

\section{Conclusions}

The results from this study showed that co-treatment of gas-phase styrene and acetone can be performed in a biofilter with high elimination capacities (212 g styrene $\mathrm{m}^{-3} \mathrm{~h}^{-1}$ and $151 \mathrm{~g}$ acetone $\mathrm{m}^{-3} \mathrm{~h}^{-1}$ ) using the fungus $S$. variecibatus.

The fungus was also able to resist high total loading rates of styrene and acetone. At an EBRT of $17.1 \mathrm{~s}$ and an $\mathrm{ILR}_{\text {Total }}$ of $553.6 \mathrm{~g} \mathrm{~m}^{-3} \mathrm{~h}^{-1}$, nearly $41.2 \%$ of the incoming gasphase pollutant was removed.

When the incoming air contained high concentrations of both acetone and styrene $\left(>4.5 \mathrm{~g} \mathrm{~m}^{-3}\right)$, acetone removal decreased in comparison to styrene that was affected only slightly $(<6 \%)$ and the degree of antagonism depended highly on the styrene loading rate.

Substrate stratification occurred along the biofilter height in terms of styrene and acetone removal that confirmed fungal activity in all sections of the biofilter.

Transient operations were performed as short-term tests, by increasing the concentrations of both styrene and acetone suddenly, to ascertain the response of the biofilter to fluctuating pollutant loads. This shock load (ILR Total $-647.2 \mathrm{~g} \mathrm{~m}^{-3} \mathrm{~h}^{-1}$ ) led to a decline in the $\mathrm{RE}$ by about 20-30\%, though high $\mathrm{EC}_{\text {Total }}$ were maintained $\left(>350 \mathrm{~g} \mathrm{~m}^{-3} \mathrm{~h}^{-1}\right)$, and complete recovery to original performance occurred almost instantaneously, when previous loading conditions were restored. 


\section{Acknowledgements}

The authors would like to thank the European FEDER funds and the Spanish Ministry of Science and Innovation, for providing financial support, through project CTM200762700 / TECNO. The help of María Montes, UDC, La Coruña, is also greatly acknowledged by the authors. Eldon R. Rene thanks the Ministry of Science and Innovation for his Juan de La Cierva-post doctoral research contract. Radka Špačková was a visiting researcher from the Institute of Chemical Technology, Prague.

\section{References}

H. Jorio, L. Bibeau, M. Heitz

Biofiltration of air contaminated by styrene: effect of nitrogen supply, gas flow rate and inlet concentration

Environ. Sci. Technol., 34 (2000), pp. 1764-1771

\section{MNTAP}

Reducing volatile emissions in the fiber reinforced plastics industry, Minnesota Technical Assistance Programme - retrieved in March (2010, From:) http://www.mntap.umn.edu/fiber/75-FRPemissions.htm

\section{E.R. Rene, M.C. Veiga, C. Kennes}

Experimental and neural model analysis of styrene removal from polluted air in a biofilter

J. Chem. Technol. Biotechnol., 84 (2009), pp. 941-948

K.P. Przybylska, K. Zieminski, T.St. Szopa

Acetone biodegradation in a trickle-bed biofilter

Int. Biodet. Biodeg., 57 (2006), pp. 200-206

\section{E.R. Rene, M.C. Veiga, C. Kennes}

Performance of a biofilter for the removal of high concentrations of styrene under steady and non-steady state conditions

J. Hazard. Mater., 168 (2009), pp. 282-290

E.R. Rene, M.C. Veiga, C. Kennes

Biotreatment of gas-phase styrene using the fungus Sporothrix variecibatus: impact of pollutant load and transient operations

Chemosphere, 79 (2010), pp. 221-227

C. Kennes, M.C. Veiga

Fungal biocatalysts in the biofiltration of VOC polluted air

J. Biotechnol., 113 (2004), pp. 305-319

C. Kennes, M.C. Veiga

Conventional biofilters

M.C. Kennes, Veiga (Eds.), Bioreactors for Waste Gas Treatment, Kluwer Academic Publishers, Netherlands (2001), pp. 47-98 
K. Chang, C. Lu

Biofiltration of toluene and acetone mixtures by a trickle-bed air biofilter

World J. Microbiol. Biotechnol., 19 (2003), pp. 791-798

M. Deshusses, C.T. Johnson, G. Leson

Biofiltration of high loads of ethyl acetate in the presence of toluene

J. Air Waste Manage. Assoc., 49 (1999), pp. 973-979

Y. Liu, X. Quan, Y. Sun, J. Chen, D. Xue, J.S. Chung

Simultaneous removal of ethyl acetate and toluene in air streams using compost-based biofilters

J. Hazard. Mater., 95 (2002), pp. 199-213

R. Dehghanzadeh, A. Torkian, B. Roshani, M. Asadi

Evaluation of biofilter performance in the co-treatment of styrene and acrylonitrile vapours mixture

M.C. Kennes, Veiga (Eds.), Proceedings of the Ist Congress on Biotechniques for Air Pollution Control, UDC-Publisher, La Coruña, Spain (2005), pp. 377-384

E.R. Rene, D.V.S. Murthy, T. Swaminathan

Performance evaluation of a compost biofilter treating toluene vapours

Proc. Biochem., 40 (2005), pp. 2771-2779

Y. Jin, L. Guo, M.C. Veiga, C. Kennes

Fungal biofiltration of $\alpha$-pinene: effects of temperature, relative humidity, and transient loads

Biotechnol. Bioeng., 96 (2007), pp. 433-443

C. Kennes, H.H.J. Cox, H.J. Doddema, W. Harder

Design and performance of biofilters for the removal of alkylbenzene vapours

J. Chem. Technol. Biotechnol., 66 (1996), pp. 300-304

D. Quesnel, G. Nakhla

Removal kinetics of acetone and MIBK from a complex industrial wastewater by an acclimated activated sludge

J. Hazard. Mater. B, 132 (2006), pp. 253-260

J. Kim, H.W. Ryu, D.J. Jung, T.H. Lee, K.-S. Cho

Styrene degradation in a polyurethane biofilter inoculated with Pseudomonas sp. IS-3

J. Microbiol. Biotechnol., 15 (2005), pp. 1207-1213

A.K. Mathur, J. Sundaramurthy, C. Balomajumder

Kinetics of the removal of mono-chlorobenzene vapour from waste gases using a trickle bed air biofilter

J. Hazard. Mater., 137 (2006), pp. 1560-1568

A.M. Gerrard, O. Misiaczek, D. Hajkova, M. Halecky, J. Paca

Steady state models for the biofiltration of styrene/air mixtures

Chem. Biochem. Eng. Q., 19 (2005), pp. 185-190 
A.A. Ramirez, S. Benard, A. Giroir-Fendler, J.P. Jones, M. Heitz

Kinetics of microbial growth and biodegradation of methanol and toluene in biofilters and an analysis of the energetic indicators

Bioresour. Technol., 138 (2008), pp. 88-95

S.J. Ergas, J. Veir, K. Kinney

Control of dichloromethane emissions using biofiltration

J. Environ. Sci. Health, A31 (1996), pp. 1741-1754

B. Qi, W.M. Moe, K.A. Kinney

Treatment of paint spray booth off-gases in a fungal biofilter

J. Environ. Eng., 131 (2005), pp. 180-189

C. Kennes, E.R. Rene, M.C. Veiga

Bioprocesses for air pollution control

J. Chem. Technol. Biotechnol., 84 (2009), pp. 1419-1436

J.R. Woertz, K.A. Kinney, N.D.F. McIntosh, P.J. Szaniszlo

Removal of toluene in a vapour-phase bioreactor containing a strain of the dimorphic black yeast Exophiala lecaniicorni

Biotechnol. Bioeng., 75 (2001), pp. 550-558

H.H.J. Cox, R.E. Moerman, S. van Baalen, W.N.M. van Heiningen, H.J. Doddema, W. Harder

Performance of styrene degrading biofilter containing the yeast Exophiala jeanselmei

Biotechnol. Bioeng., 53 (1997), pp. 259-266

E.R. Rene, M.E. López, M.C. Veiga, C. Kennes

Steady- and transient-state operation of a two-stage birreactor for the treatment of a gaseous mixture of hydrogen sulphide, methanol and $\alpha$-pinene

J. Chem. Technol. Biotechnol., 85 (2010), pp. 336-348

A.P. Carden, G. Hamer

Aerobic biotreatment of acetone and methanol in a continuous flow bioreactor during unsteady state operation

Bioproc. Eng., 16 (1997), pp. 119-125

A.A. Hassan, G.A. Sorial

Biofiltration of $n$-hexane in the presence of benzene vapors

J. Chem. Technol. Biotechnol., 85 (2010), pp. 371-377

W.C. Chan, T.Y. Lai

Interaction of compounds on biodegradation of ketone mixtures in a biofilter

J. Chem. Technol. Biotechnol., 85 (2010), pp. 416-422 